Journal of Pentecostal Theology 


\section{Journal of Pentecostal Theology}

\section{Editors}

Lee Roy Martin, Pentecostal Theological Seminary, USA

John Christopher Thomas, Pentecostal Theological Seminary, USA

\section{Associate editors}

Daniela C. Augustine, University of Birmingham, $U K$

Chris E.W. Green, Southeastern University, USA

Robby Waddell, Southeastern University, USA

\section{Founding Editors}

Steven J. Land, Pentecostal Theological Seminary, USA

Rickie D. Moore, Lee University, USA

John Christopher Thomas, Pentecostal Theological Seminary, USA

\section{Editorial board}

Simon K.H. Chan, Trinity Theological College, Singapore

Blaine Charette, Northwest University, USA

Cheryl Bridges Johns, Pentecostal Theological Seminary, USA

Peter Kuzmič, Gordon-Conwell Theological Seminary, USA, and Evangelical Theological Seminary, Croatia)

Frank D. Macchia, Vanguard University, USA

Opoku Onyinah, Pentecost University College, Ghana

Norberto Saracco, International Faculty of Theological Studies, Argentina

Juan Sepúlveda, SEPADA, Chile

Eldin Villafañe, Gordon-Conwell Theological Seminary, USA

Willie J. Wessels, University of South Africa, South Africa

Volumes published in this journal are listed at brill.com/pent 


\title{
Journal of Pentecostal Theology
}

VOLUME $31(2022)$

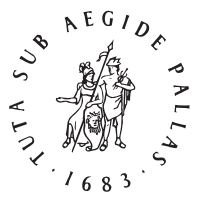 \\ B R I L L \\ LEIDEN | BOSTON
}


Brill Open Access options can be found at brill.com/openaccess.

Typeface for the Latin, Greek, and Cyrillic scripts: "Brill”. See and download: brill.com/brill-typeface.

ISSN 0966-7369

E-ISSN 1745-5251

Copyright 2022 by Koninklijke Brill Nv, Leiden, The Netherlands.

Koninklijke Brill NV incorporates the imprints Brill, Brill Nijhoff, Brill Hotei, Brill Schöningh, Brill Fink, Brill mentis, Vandenhoeck \& Ruprecht, Böhlau Verlag and V\&R Unipress.

All rights reserved. No part of this publication may be reproduced, translated, stored in a retrieval system, or transmitted in any form or by any means, electronic, mechanical, photocopying, recording or otherwise, without prior written permission from the publisher. Requests for re-use and/or translations must be addressed to Koninklijke Brill NV via brill.com or copyright.com.

Brill has made all reasonable efforts to trace all rights holders to any copyrighted material used in this work. In cases where these efforts have not been successful the publisher welcomes communications from copyright holders, so that the appropriate acknowledgements can be made in future editions, and to settle other permission matters.

This journal is printed on acid-free paper and produced in a sustainable manner. 